\title{
Research on Characteristics, Opportunities and Strategies of Exhibition Industry of Guangxi Xinyu Xiong ${ }^{1, a}$
}

\author{
${ }^{1}$ Guilin Tourism University, Guilin, 541000, China \\ aemail
}

\begin{abstract}
Keywords: Exhibition Industry, Strategies planning, Development strategies
\end{abstract}
\begin{abstract}
The exhibition industry, as a sunrise industry in modern society, has played an important role in Guangxi's economic construction in recent years. Modern exhibition industry in Guangxi has the characteristics of great in number and high in quality. In the face of the strategic opportunity of "The Belt and Road" and the China ASEAN Expo, the exhibition industry in Guangxi should implement the strategy of scaling up, specialization and internationalization, and strive to build Guangxi into a great province of exhibition industry with international influence.
\end{abstract}

\section{Characteristics of the Exhibition Industry Development in Guangxi}

Great in Number. After the reform and opening up, the number of exhibition halls in Guangxi keeps increasing, with the exhibition area expanding significantly and the number of exhibitions growing by leaps and bounds. In 1978, Guangxi Science and Technology Museum and Museum was built. From 1987 to 1999, Guilin International Trade Exhibition Center, a compound of exhibitions, conferences, trade and tourism, was finished with the investment from the State Ministry of Foreign Trade and Economic Cooperation, Guangxi Foreign Trade and Economic Cooperation Department, and Guilin Municipal People's Government successively. The exhibition area has also increased significantly, including Nanning International Convention and Exhibition Center with the exhibition area of 80,000 square meters for 3600 international standard booths, Guangxi Exhibition Hall with 38,000 square meters for 1600 booths and Guangxi Science and Technology Museum of 19,000 square meters. There are other non-international standard halls, such as the Guangxi Automobile Market People's Hall with a total area of 152,000 square meters. Exhibition facilities and supporting services are also constantly improving and updating. In recent years, Guangxi holds 50-60 exhibitions every year. The scale of the exhibitions has been expanding, and the exhibitions with more than 1000 booths continue to increase, which attracts foreign exhibitors to Guangxi to hold industry or professional exhibition. The exhibition industry in Guangxi show great vitality. Famous exhibitions in Guangxi include China - ASEAN Expo, China ASEAN Business and Investment Summit, Nanning International Folk Song Festival, Nanning International Student Supplies Fair, Guangxi Automobile Fair, Guangxi International Auto Show, Guangxi Housing Fair, Guangxi Binyang Cannon Festival, Guangxi Wuming March Three Songs Fair, Guangxi Wuzhou Gem Festival, Hengxian Jasmine Festival and so on. The number of exhibitors and participators form foreign countries and other provinces and cities increases significantly, the proportion of well-known exhibitors grows, and the number of buyers with actual willingness of purchases increases. In conclusion, with the increase and development of exhibition infrastructure, the economic and social benefits brought by exhibition to Guangxi Province have significantly improved.

High in Quality. Years of continuous exhibitions creates a good brand image for Guangxi exhibition industry. From 1992 to 2017, 26 consecutive sessions have been held. Guangxi Investment and Trade Fair also held for many times. In September 2016, Guangxi Investment and Trade Fair held in Nanning reached a total of 24 investment projects, and achieved fruitful results. The Nanning Folk Song Festival held in May 2016 was the 19th Nanning Folk Art Festival. Continuous exhibitions make Nanning become a city of folk song. In recent years, Guangxi, through the full integration of geographical advantages and characteristics of the festival, hold many special exhibitions, such as Sino-Vietnamese Border Trade (Pingxiang) Fair, Mango Festival of Baise region, and Tourism 
Products Trade Fair in Guilin. These exhibitions focus on the benefits of exhibitors, and provide customers with a wide range of trade negotiations as far as possible. The investments and projects reached and signed in the exhibition are impressive. Significant economic and social benefits make these exhibitions become popular events and favor by exhibitors and merchants. Since Nanning successfully held the China-ASEAN Expo in 2004, China-ASEAN Expo has become one of the top ten well-known exhibitions brand domestically. In the past, there were few professional exhibitions held in Guangxi. In recent years, with the opening of the exhibition market, the exhibition companies in nearly 10 cities of Beijing, Shanghai, Wuhan, Guangzhou, Chengdu, Chongqing and Dalian have gradually expanded the scale of professional exhibitions in Guangxi. The exhibitions cover building materials, medicine, machinery and home appliances, electronic, advertising, clothing, sound, beauty salons and many other aspects, which not only activates the Guangxi exhibition market, but also promotes the development of related industries in Guangxi, helping Guangxi enterprises in the exhibition to better understand the peer production information, timely adjustment of product structure, improve quality, and better participate in market competition.

\section{Opportunities of the Development of Exhibition Industry in Guangxi}

The Belt and Road. "The Belt and Road" is the abbreviation for "Silk Road Economic Zone" and "21st Century Maritime Silk Road". ASEAN is China's first stop for implementing the " The Belt and Road " strategy, and plays a key role for the successful construction of " The Belt and Road ". As a forward station of exchanges and cooperation between China and ASEAN, Guangxi has a lot of opportunities in the construction of "21st Century Maritime Silk Road". The exhibition industry will usher in greater room for development. Under the influence of the strategy, the economic status of Guangxi is becoming more and more important in the ASEAN countries, and its geographical advantages are becoming more and more obvious. " The Belt and Road " will attract more countries and enterprises to join the framework of economic cooperation, bringing more business opportunities of negotiations to Guangxi as well as some new challenges to the exhibition economy in Guangxi. In recent years, Guangxi, relying on the coastal port, border port and the West River gold waterway, improves and enhances integrated transport system that connects southwest and central south and reaches ASEAN directly, to reduce costs and shorten the time for the logistic of businesses in the free trade zone and reduce the burden on the enterprise. Under such an opportunity, Guangxi multilateral trade will realize an unprecedented development, involving more industries and more complex types of goods, which proposes higher requirements on the industrial professionalism of exhibition activities. China - ASEAN Expo and China Guilin International Tourism Expo held every year in Guangxi effectively promote cooperation between Guangxi and ASEAN countries in the business, tourism and other aspects. It can be expected that with the promotion of "The Belt and Road " strategy, the grade of the two exhibitions are expected to make further improvement, bringing more benefits to local economic development.

China-ASEAN Expo. China-ASEAN Free Trade zone is a free trade zone set up by China and ASEAN countries. It was formally completed in January 1, 2010. The establishment of China ASEAN Free Trade Zone creates opportunities for the exhibition industry in Guangxi. China ASEAN Free Trade Zone is the free trade zone with the largest population in the world. It has nearly 1.7 billion people, with nearly $\$ 2$ trillion in gross domestic production and nearly $\$ 1.2$ trillion in total trade. These figures give Nanning, the permanent venue for ASEAN Expo, great opportunities to develop regional economy. The settle of China - ASEAN Expo in Nanning, Guangxi pushes Guangxi to the center of regional cooperation with ASEAN from the height of the national strategy. After the completion of the free trade zone, bilateral trade between China and ASEAN will increase substantially, and trade in services such as tourism, finance and labor cooperation will also develop rapidly. Due to the geographical advantages of its location, Guangxi, as the center of connecting ASEAN countries, the future free trade zone of modern logistics and resource investment and development center, will bring a good follow-up effect to Guangxi exhibition economy. With the construction of China - ASEAN Free Trade Zone, the dominant position of Guangxi in the domestic 
and international regional development strategy is highlighted. Guangxi is firmly grasping the great opportunity of regional economic integration to be actively involved in the Pan-Pearl River Delta, Southwest cooperation and other domestic economic cooperation on the one hand, and to continue to promote the Pan-Beibu Gulf regional economic cooperation as the focus of China-ASEAN transnational regional economic cooperation on the other hand. This expand will play a significant role in promoting the development of Guangxi exhibition space and enhancing the development of the exhibition economy.

\section{Development Strategies of Exhibition Industry in Guangxi}

Standardization. As a new industry, the exhibition industry has strong professionalism, comprehensiveness, topicality and competitiveness, which determines the development of the exhibition industry cannot be completely controlled by the market, but must be government-led. In addition, China's exhibition industry development is still in the initial stage, so the government should play an active role in the macro-control, legal norms, financial support. Although the exhibition industry in Guangxi is developing towards a healthy market direction, in the process of marketization, Guangxi governments at all levels should also play the role of good macro-controller, accurately grasping the scale, status, nature and characteristics of the exhibition, organizing and managing Guangxi exhibition industry in accordance with the new ideas, and form the management system and operation mechanism of exhibition management in line with international practice and market economy. The government should also do a good job in the industry standard management, create the exhibition organizers qualification assessment system, replace qualifications with aptitudes, to form multi-level market system and standardize market competition. At the same time, the government needs to regulate the administrative examination and approval and make processes simple and fees reasonable as far as possible; reduce the threshold of market entry, to encourage more private enterprises to enter the exhibition industry and develop the exhibition industry market. The government needs to promulgate the corresponding policy and establish and improve preferential facilities for exhibitions in Guangxi and enterprises who invest the exhibition in Guangxi, to attract foreign exhibition companies to Guangxi to open up the market, promote the cooperation between Guangxi exhibition industry and international exhibition industry. What's more, the government should speed up the construction of Guangxi exhibition venues and supporting facilities and integrate existing resources, to include the exhibition infrastructure into the overall planning of urban development of Guangxi step by step and take the development of exhibition industry as a driver for the better and faster development of the economy in Guangxi.

Specialization. Specialization is an important source of vitality of the exhibition and an inevitable choice for the development of exhibition industry in Guangxi. Exhibition units and exhibition companies should strengthen the planning of the exhibition content, based on a specific industry and connecting with the development of the industry in order to leave a deep impression to the exhibitors and the audience. Exhibitions with similar contents and theme should be reduced. Venues should have a clearer dominant function positioning. Guangxi exhibition industry should learn from successful experience in foreign countries, strengthen the China - ASEAN Expo brand, and, at the same time, according to the Guangxi industry characteristics, dig out potential exhibition projects. To further improve the professional level of the exhibition industry in Guangxi, the venue construction should be based on specific industries and in close connection with the development of the industry and local economic trends, explicit theme positioning, to achieve functional specialization; exhibition units and exhibition companies should strengthen the planning contents, to specify the theme and contents of the exhibitions. This is both easy for the exhibition company and venue owners to carry out long-term cooperation and conducive to nurturing exhibition brand. At present, the strategy of Guangxi's exhibition industry is not efficient enough. It is imperative to upgrade the specialization and brand effect of China-ASEAN Expo as soon as possible, establish a database of China-ASEAN Expo, set up a large-scale exhibition company with the help of the database, provide professional manpower, technology and equipment to assist the planning, preparation, registration, meeting to the 
closure of the work, according to the contract signed. The development of China-ASEAN Expo and the Beibu Gulf Economic Zone should be used to improve the exhibition industry system support, to create the unique brand of the exhibition industry in Guangxi.

Internationalization. The internationalization of the exhibition industry is a sign that the exhibition industry is mature. The exhibition industry in Guangxi should strengthen international cooperation and promote exchanges and cooperation with international exhibition organizations, international exhibition management associations, international exhibition bureaus and other international exhibition organizations; run the exhibitions according to international practice and international rules and try to activate the exhibition through the joint office and other forms; open the exhibition market, introduce international competition mechanism through the introduction of foreign companies or joint venture exhibition, learn advanced exhibition concept and management experience from foreign countries, and promote the progress of the exhibition process and the prosperity of exhibition market through market competition; encourage the exhibition enterprises go to the international market, in particular, to the ASEAN countries to hold Guangxi Commodities Fair, consolidate the results achieved in Guangxi - Vietnam, Guangxi - Thailand, Guangxi - Indonesia Commodities Fair, strive to hold Guangxi Commodities Fair in more ASEAN countries, and speed up the internationalization of Guangxi exhibition industry through domestic and international markets; invite relevant units or organizations in ASEAN countries to co-host, undertake or co-operate in all large-scale exhibitions and festivals are held in Guangxi, to deepen their friendship, build trust and seek cooperation in the process of working together; jointly promote the development of the exhibition industry in Guangxi through deepening the exchanges and communication between Guangxi and other exhibition city, exhibition industry organizations, exhibition enterprises and around the theme of "China - ASEAN Trade Zone". The exhibition industry in Guangxi must take the road of internationalization, establish a sense of competition and cooperation, and carry out joint cooperation of various forms and contents with an open, cooperative and win-win attitude.

\section{Conclusions}

The exhibition industry, as a new industry, has huge market potential and high economic returns potential. The exhibition industry Guangxi is great in number and high in quality. Guangxi should seize the strategic opportunities under the new situation and take the road of standardization, specialization and internationalization, to enhance the competitive position of Guangxi exhibition industry in the domestic and international exhibition market, and fully tap the potential economic return of the exhibition economy to promote the development of Guangxi's economy.

\section{References}

[1] Wen C. On Training of Interpreters of Guangxi under the Development of Convention and Exhibition Economy [J]. Journal of Hainan Radio \& TV University, 2015(1): 003.

[2] Xian Z. The Practice of and Consideration about Library's Exhibition Service-Taking Guangxi Guilin Library as an Example [J]. Sci-Tech Information Development \& Economy, 2014(11): 005.

[3] Lin Zongding. On Sustainable Hosting of Garden and Horticulture Exposition in Guangxi [J]. 2014(7): 61-63.

[4] Tang Qizhan, Yu Fangfang, Liu Heyang. On the Great-leap-forward Development of Guangxi MICE Industry [J]. Journal of Guangxi University of Finance and Economics, 2013, 26(1): 54-58. 